\title{
PENINGKATAN KUALITAS PRODUK OLAHAN JAMU TRADISIONAL PADA MASA PANDEMI COVID-19 DI DESA KOLAM
}

\section{IMPROVING THE QUALITY OF PROCESSED TRADITIONAL HERBAL PRODUCTS DURING THE COVID-19 PANDEMIC IN KOLAM VILLAGE}

\author{
Winsyahputra Ritonga ${ }^{1)}$, Fitrawaty ${ }^{2)}$ Deo Demonta Panggabean ${ }^{3)}$, Maya Oktora ${ }^{4)}$, \\ Mukti Hamjah Harahap ${ }^{5)}$, Irfandi ${ }^{6}$, Dedy Husrizal Syah ${ }^{7)}$ \\ 1,3,5,6 Jurusan Fisika, Universitas Negeri Medan \\ ${ }^{2,7}$ Jurusan Ekonomi, Universitas Negeri Medan \\ ${ }^{4}$ Jurusan Bahasa Inggris, Universitas Negeri Medan \\ ${ }^{7}$ Email: dedy@unimed.in
}

\begin{abstract}
Abstrak: Kegiatan pengabdian pada masyarakat ini dilaksanakan di Desa Kolam Kecamatan Percut Sei Tuan Kabupaten Deli Serdang, Sumatera Utara. Permasalahan yang dihadapi mitra yaitu teknologi pengolahan masih tradisional sehingga mitra mengalami kesusahan dalam memenuhi kuantitas yang dibutuhkan dalam waktu singkat, khususnya teknologi dalam pemerasan dan penggiling bahan baku, dan penyusunan laporan keuangan. Sehubungan dengan permasalahan yang dihadapi mitra, maka pada program pengabdian kepada masyarakat ini akan diwujudkan dengan mentransferkan alat/mesin penggiling jamu, pelatihan pembukuan dan manajemen keuangan. Metode yang digunakan untuk mencapai tujuan kegiatan pengabdian ini adalah metode pendidikan, sosialisasi, pendampingan peningkatan produk, pelatihan pembukuan dan manajemen usaha. Hasil kegiatan ini berupa telah diberikannya alat TTG Mesin penggiling jamu, serta diadakannya pelatihan serta pendampingan manajemen usaha dan pembukuan keuangan. Tingkat keberhasilan dari kegiatan pengabdian pada masyarakat di buktikan dengan peningkatan produksi, pendapatan dan pengetahuan mitra
\end{abstract}

Kata Kunci: TTG, Mesin penggiling jamu, Pelatihan, Pendampingan

\begin{abstract}
This community service activity was carried out in the Kolam Village, Percut Sei Tuan District, Deli Serdang Regency, North Sumatra. The problem faced by partners is that the processing technology is still traditional so that partners have difficulty in meeting the required quantity in a short time, especially technology in squeezing and grinding raw materials, and preparing financial reports. In connection with the problems faced by partners, this community service program will be realized by transferring herbal grinding tools/machines, bookkeeping and financial management training. The methods used to achieve the objectives of this service activity are methods of education, socialization, product improvement assistance, bookkeeping and business management training. The result of this activity is the provision of a herbal medicine grinding machine TTG
\end{abstract}


INTEGRITAS : Jurnal Pengabdian

Vol 5 No 2 Desember 2021

ISSN 2580 - 7978 (cetak) ISSN 2615 - 0794 (online)

tool, as well as training and assistance in business management and financial bookkeeping. The success rate of community service activities is proven by increasing production, income and partner knowledge.

Keywords: TTG, Jamu grinder machine, Training, Mentoring

\section{PENDAHULUAN}

Keberadaan UKM di Indonesia masih sangat diperlukan dalam menopang perekonomian di Nasional. Krisis global tahun 1997 membuktikan bahwa UKM adalah salah satu sector yang mampu bertahan menghadapi gempuran krisis. Selain itu di tahun 2008 juga tercatat bahwa UKM menunjukkan peningkatan besaran Produk Domestik Bruto pada tahun 2008 mencapai nilai Rp.1.013,5 Triliun (56,7\%dari PDB), dengan jumlah UKM mencapai 42,4 juta (Mochamad Reza Rahman et al., 2013). Keberadaan UKM disisi lain ingin dikembangkan ternyata juga memiliki keterbatasan-keterbatasan. Para UKM sering mengalami ketertinggalan dalam berbagai aspek, seperti; informasi, pengelolaan manajemen usaha, keterbatasan teknologi produksi, modal, jejaring, dll, sehingga berdampak negatif pada keingginan untuk membesarkan usahanya. Kesinergian antara para pelaku UKM dan peran lembaga-lembaga diluarnya dalam membangun usaha yang berdaya saing mutlak diperlukan. Banyak jenis usaha yang digeluti oleh UKM di Indonesia, mulai dari kuliner sampai kerajinan, mulai berbasis sumber daya local sampai pengembangan produk internasional. Salah satu jenis usaha yang digeluti UKM adalah jamu. Jamu merupakan minuman tradisional bangsa Indonesia yang bersumber pada bahan baku lokal dan spesifik di Indonesia (Murniati, 2020).

Berdasarkan data Convention on Biological Deversity, bahwa pasar obat herbal beberapat tahun terakhir tercatat sebesar US\$43 milyar. WHO menyebutkan pasar obat herbal yang terbesar adalah: RRC U\$ 9milyar, EU US\$ 6 milyar, USA US\$ 3 milyar, Jepang US \$ 2 milyar dan Kanada US\$ 1milyar (Le Prestre, 2017). Demikian pula pasar obat herbal diIndonesia juga terus meningkat dari Rp. 1,3 triliun menjadi sekitar Rp.2,5 triliun (Widowati et al., 2020). Secara ekonomi, industri jamu Indonesia telah menunjukkan pertumbuhan yang signifikan dengan nilai penjualan mencapai Rp 6 triliun, telah menciptakan tiga 
INTEGRITAS : Jurnal Pengabdian

Vol 5 No 2 Desember 2021

ISSN $2580-7978$ (cetak) ISSN 2615 - 0794 (online)

juta lapangan kerja,dan dengan daerah konsumen terbesar di pulau Jawa mencapai 60\% di tahun 2000 (Saptaningtyas \& Indrahti, 2000).

Meskipun cukup prospek, usaha ini juga memiliki berbagai permasalahan diantaranya, masih marak peredaran jamu berbahan baku kimia dan makin memprihatinkan yang berpotensi mencemarkan perkembangan jamu tradisional. Selain itu, produk jamu impor yang dengan mudah ditemukan dipasar dalam negeri juga memberikan dampak yang rentan terhadap persaingan dan citra jamu terutama bagi industri skala kecil. Hal ini dikarenakan kemampuan dan daya saing produk jamu dari usaha kecil yang belum terstandarisasi sesuai dengan Cara Pembuatan Obat Tradisional yang Baik. Beberapa permasalahan yang hari ini dihadapi pengusaha jamu antara lain;(1) teknologi pengolahan masih manual; (2) Masalah banyaknya jamu ilegal dan jamu palsu yang beredar di masyarakat, serta Masalah standarisasi mutu jamu; (3) Masalah preferensi pelanggan terhadap jamu cair; (4) Masalah pengetahuan masyarakat pengguna terhadap jamu (uji klinis, edukasi pelanggan) (Setyo, 2017).

Desa Kolam merupakan salah satu desa yang ada di Kecamatan Percut Sei Tuan Kabupaten Deli Serdang. Sejak 2007, sudah terbentuk kelompok wirausaha jamu yang terletak dalam satu daerah yang sama. Kurang lebih ada 15 keluarga yang berwirausaha sebagai pembuat dan penjual jamu yang terkumpul dalam satu lorong yang sama. Pelanggannya pun sudah tersebar diseluruh Kecamatan Percut sei tuan, sebab kelompok ini berjualan secara keliling dengan berjalan kaki,dan ada juga yang berjualan pada satu tempat tertentu. Dahulu bahan baku bersumber dari tanaman obat yang dibangun oleh pihak kelurahan dan kecamatan, akan tetapi sekarang bahan baku tersebut sudah diperoleh dari tempat lain.

Berdasarkan hasil pengamatan awal diketahui bahwa sistem pengolahan jamu masih bersifat tradisional dengan produk unggulan berbentuk cair. Sehingga kemampuan pengolahan tersebut diwariskan secara turun temurun pada anggota keluarga lainnya. Akan tetapi seiring dengan peningkatan kebutuhan pasar pengusaha jamu juga dituntut untuk meningkatkan kuantitas produknya. Hasil wawancara awal diketahui bahwa pengusaha jamu mengalami kesusahan dalam memproduksi dalam waktu yang cepat, apalagi bila ada permintaan yang banyak. 
Proses produksi yang memakan waktu lama adalah proses pemarutan bahan baku, sebab masih menggunakan peralatan tradisional. Selain masalah produksi tersebut, pengusaha jamu cenderung mengabaikan brand dan kemasan produk, sehingga usaha yang sudah dijalani selama ini tidak begitu banyak dikenal orang status kepemilikannya.

Mitra PKM disini yaitu Kelompok Usaha Jamu Harum dan Segar Sari. Lokasi usaha ini terletak di Desa Kolam Kecamatan Percut Sei Tuan Kabupaten Deli Serdang. Penghasilan produksi jamu ini rata-rata perbulannya sekitar Rp.2.500.000,-. Untuk pemasaran jamu ini ada agen yang mengambilnya setiap hari. Yang menjadi permasalahan pada mitra yaitu diperlukannya pengetahuan tentang teknologi tepat guna yaitu alat peras jamu yang masih manual dan belum adanya sertifikasi halal. Kondisi manajemen laporan keuangan yang diterapkan dalam usaha jamu yang dikelola Ibu Sonimin ini masih menggunakan manajemen laporan keuangan secara kekeluargaan (bagi hasil) dan belum dikelola sebagaimana mestinya.

Adapun permasalahan yang dihadapi Mitra 1 dan Mitra 2 serta permasalahan prioritas yang disepakati untuk diselesaikan bersama pada program kemitraan masyarakat ini dapat dilihat seperti pada Tabel 1 berikut.

Tabel 1. Permasalahan Kedua Mitra dan Permasalahan Prioritas

\begin{tabular}{|c|c|c|c|}
\hline No & Permasalahan Mitra 1 & Permasalahan Mitra 2 & Permasalahan Prioritas \\
\hline 1 & $\begin{array}{l}\text { Peralatan produksi masih } \\
\text { manual produksi terbatas } \\
\text { menyebabkan waktu } \\
\text { produksi yang lama dan } \\
\text { kuantitas produksi yang } \\
\text { tidak maksimal }\end{array}$ & $\begin{array}{l}\text { Peralatan produksi } \begin{array}{r}\text { masih } \\
\text { menggunakan }\end{array} \text { tangan } \\
\text { menyebabkan mitra kesulitan } \\
\text { dalam menyelesaikan pesanan } \\
\text { jamu dalam jumlah banyak } \\
\text { pada acara/hari tertentu. }\end{array}$ & $\begin{array}{l}\text { Peralatan produksi yang } \\
\text { digunakan masih manual } \\
\text { untuk usaha penggilingan } \\
\text { jamu yang mempengaruhi } \\
\text { kuantitas produk dan } \\
\text { waktu produksi. }\end{array}$ \\
\hline 2. & $\begin{array}{l}\text { Minimnya modal usaha } \\
\text { yang dimiliki sehingga } \\
\text { belum mampu membeli } \\
\text { peralatan yang mahal }\end{array}$ & $\begin{array}{lrr}\text { Modal usaha yang } & \text { kecil } \\
\text { sehingga } & \text { mitra belum mampu } \\
\text { membeli peralatan } & \text { dengan } \\
\text { kapasitas besar } & \text { yang } \\
\text { diperuntukkan khusus } & \text { untuk } \\
\text { usaha jamu } & & \\
\end{array}$ & $\begin{array}{l}\text { Minimnya modal usaha } \\
\text { menyebabkan mitra tidak } \\
\text { mampu membeli peralatan } \\
\text { yang dibutuhkan dalam } \\
\text { menjalankan usahanya }\end{array}$ \\
\hline 3. & 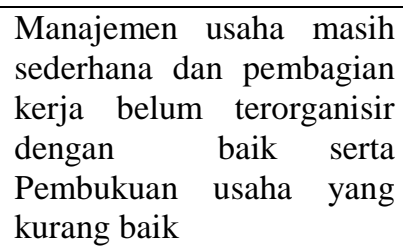 & $\begin{array}{l}\text { Manajemen usaha masih } \\
\text { sederhana serta Pembukuan } \\
\text { sudah cukup baik dan rapi } \\
\text { namun masih dilakukan secara } \\
\text { manual }\end{array}$ & $\begin{array}{l}\text { Manajemen usaha masih } \\
\text { sederhana dan pembagian } \\
\text { kerja belum terorganisir } \\
\text { dengan baik, Pembukuan } \\
\text { kurang baik dan masih } \\
\text { dilakukan secara manual }\end{array}$ \\
\hline
\end{tabular}




\section{METODE}

Metode pendekatan yang ditawarkan dalam pelaksanaan program akan dilakukan yaitu dengan membangun kemitraan antara tim pengusul dan LPPM Universitas Negeri Medan dengan pemerintahan Desa dan mitra. Metode yang akan digunakan berupa pelatihan dan praktik, workshop pembuatan TTG dan pendampingan. Tahapan kegiatan, metode dan partisipasi mitra dalam pelaksanaan kegiatan pengabdian masyarakat skema program kemitraan masyarakat yang akan dilakukan dapat diuraikan dalam Tabel 2 berikut.

Tabel 2. Tahapan Kegiatan, Metode dan Partisipasi Mitra

\begin{tabular}{|c|c|c|c|}
\hline No & Tahapan kegiatan & Metode & Partisipasi Mitra \\
\hline 1 & $\begin{array}{l}\text { Melakukan kunjungan } \\
\text { kepada mitra }\end{array}$ & $\begin{array}{l}\text { Diskusi permasalahan } \\
\text { yang dihadapi mitra }\end{array}$ & $\begin{array}{l}\text { Memberikan masukan kepada } \\
\text { tim untuk mengetahui } \\
\text { permasalahan yang dihadapi }\end{array}$ \\
\hline 2 & $\begin{array}{l}\text { FGD perencanaan solusi } \\
\text { teknologi yang akan } \\
\text { dilakukan }\end{array}$ & $\begin{array}{l}\text { Diskusi tentang } \\
\text { kebermanfaatan teknologi } \\
\text { yang akan dibuat }\end{array}$ & $\begin{array}{l}\text { Memberikan masukan kepada } \\
\text { tim agar teknolgi yang } \\
\text { dirancang akan memberikan } \\
\text { dampak yang positif bagi } \\
\text { peningkatan usaha }\end{array}$ \\
\hline 3 & $\begin{array}{l}\text { Membuat alat teknologi } \\
\text { tepat guna }\end{array}$ & Kerja di bengkel produksi & $\begin{array}{l}\text { Memonitoring alat yang di } \\
\text { rancang sehingga tepat guna }\end{array}$ \\
\hline 4 & \begin{tabular}{ll}
\multicolumn{2}{l}{ Melaksanakan } \\
penyerahan alat kepada \\
mitra disertai & Praktik \\
dan Uji & Operasi \\
Penggunaan & Peralatan \\
TTG & \\
\end{tabular} & $\begin{array}{l}\text { Seremoni penyerahan alat } \\
\text { teknologi tepat guna } \\
\text { disertai Praktik dan } \\
\text { demonstrasi penggunaan } \\
\text { alat TTG }\end{array}$ & $\begin{array}{l}\text { Menyediakan tempat dan sarana } \\
\text { dalam acara penyerahan alat } \\
\text { TTG Mesin penggiling dan alat } \\
\text { lainnya serta mengikuti praktik } \\
\text { dan uji penggunaan alat TTG }\end{array}$ \\
\hline 5 & $\begin{array}{l}\text { Melaksanakan Pelatihan } \\
\text { dan Pendampingan } \\
\text { Manajemen usaha dan } \\
\text { pembukuan sederhana } \\
\text { berbasis aplikasi }\end{array}$ & $\begin{array}{l}\text { Pelatihan } \\
\text { Pendampingan }\end{array}$ & $\begin{array}{l}\text { Mengikuti pelatihan dan } \\
\text { pendampingan dengan serius } \\
\text { dan aktif bertanya tentang } \\
\text { penggunaan aplikasi }\end{array}$ \\
\hline 6 & $\begin{array}{l}\text { Melaksanakan evaluasi } \\
\text { program }\end{array}$ & $\begin{array}{l}\text { Pengamatan } \\
\text { wawancara mitra }\end{array}$ & $\begin{array}{l}\text { Memberikan masukan tentang } \\
\text { program yang dilaksanakan }\end{array}$ \\
\hline
\end{tabular}

\section{HASIL DAN PEMBAHASAN}

Pengabdian IbM dalam program Peningkatan Kualitas Produk Olahan Jamu Tradisional Pada Masa Pandemi Covid-19 Di Desa Kolam Kecamatan Percut Sei Tuan Kabupaten Deli Serdang ini telah dilaksanakan sejak bulan Juli 2021. Adapun kegiatan-kegiatan yang telah dilakukan meliputi tahapan sebagai berikut: 
1. Persiapan

a. Persiapan (koordinator tim pelaksana dengan LPM dan Usaha mitra) yang dilaksanakan pada tanggal 28 Juni 2021.

b. Tim pengabdi melakukan Pengurusan perizinan kepada aparatur desa yang dijadikan lokasi pengabdian.

c. Ketua tim bersama anggota pengabdi menyusun jadwal kegiatan dan melakukan pembagian kerja yang dilaksanakan pada tanggal 3 Juli 2021.

2. Operasional Kegiatan

a. Tim pengabdi melakukan Sosialisasi untuk pemantapan kegiatan yang dilaksanakan pada tanggal 10 Juli 2021.

b. Pengumpulan bahan dan peralatan yang dibutuhkan dalam kegiatan Peningkatan Kualitas Dan Sertifikasi Produk Olahan Jamu Tradisional yang dilaksanakan pada tanggal 17 Juli 2021.

c. Penyerahan Mesin Penggiling Jamu yang diserahkan kepada mitra pada 31 Juli 2021 serta mendemonstrasikan penggunaannya.

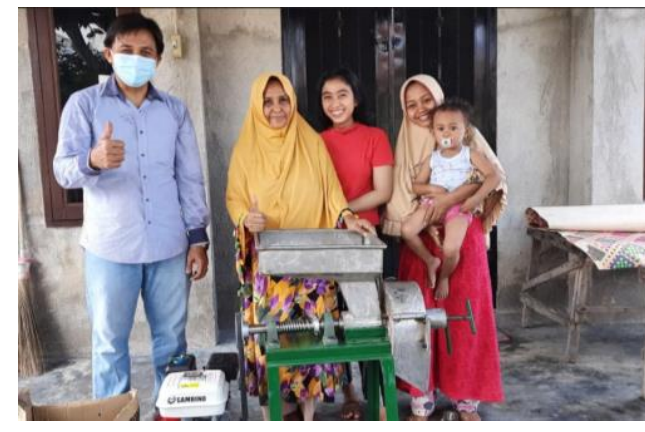

Gambar 1. penyerahan alat TTG

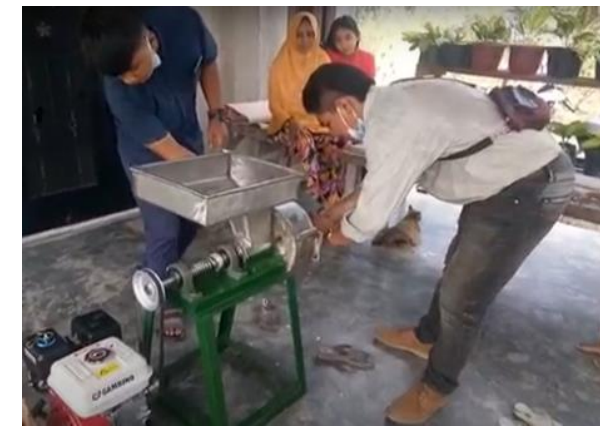

Gambar 2. demonstrasi penggunaan alat

d. Pelatihan pembukuan keuangan pada tanggal 07 Agustus 2021 dan Pelatihan manajemen dan administrasi Usaha. 


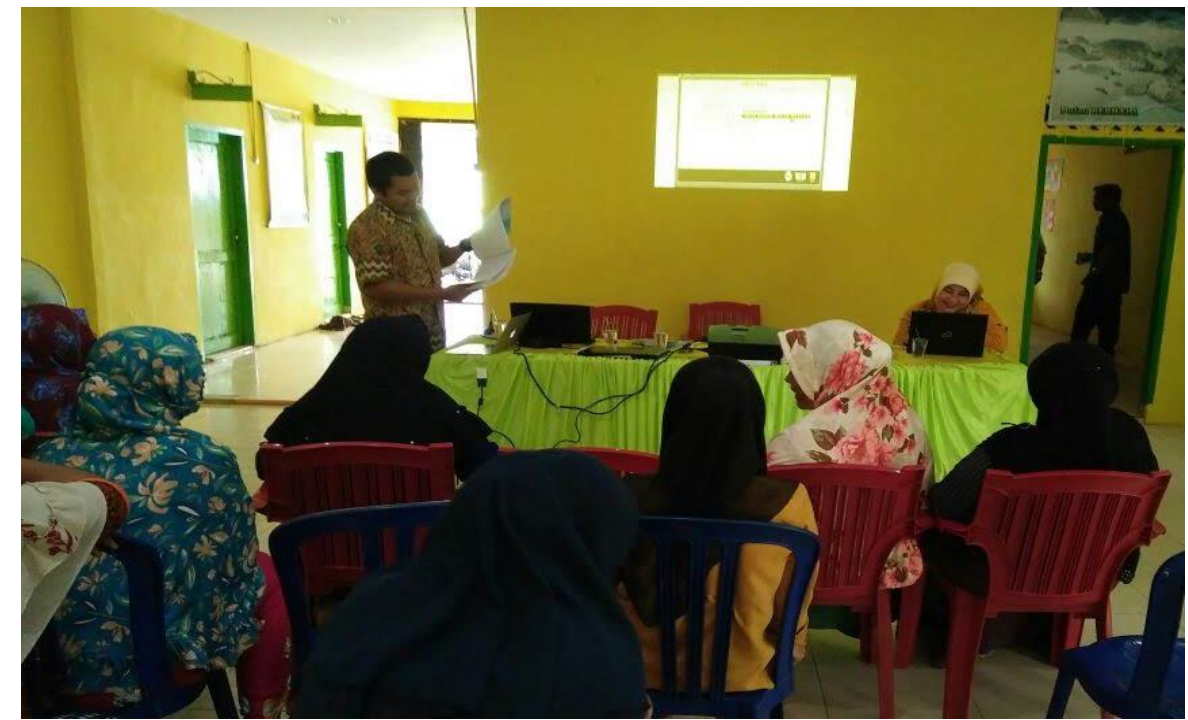

Gambar 3. Pelatihan dan Pendampingan Pembukuan

Tabel 3. Perbandingan produksi dan kualitas Usaha Jamu sebelum dan setelah program

\begin{tabular}{|c|c|c|c|}
\hline No & Aspek & $\begin{array}{c}\text { Sebelum diterapkan } \\
\text { Program }\end{array}$ & Setelah diterapkan Program \\
\hline 1 & Produksi & $2 \mathrm{~kg}$ & $5-8 \mathrm{~kg}$ \\
\hline 2 & Pendapatan & $\begin{array}{l}\text { Perbulan } \\
2.500 .000,-\end{array}$ & $\begin{array}{llll}\text { Perbulan } & \text { Rp. } & 5.000 .000 & - \\
6.000 .000 & & & \\
\end{array}$ \\
\hline 3 & Pembukuan & $\begin{array}{ll}\text { Laporan } & \text { keuangan } \\
\text { acak-acakan } & \end{array}$ & $\begin{array}{l}\text { Laporan Keuangan pembukuan } \\
\text { rapi, dah dapat memantau } \\
\text { ketersedian kas per aktivitas }\end{array}$ \\
\hline 4 & Manajemen usaha & $\begin{array}{l}\text { Belum memahami } \\
\text { teknis manajemen usaha }\end{array}$ & $\begin{array}{l}\text { Mampu melakukan manajemen } \\
\text { usaha baik itu penetapan harga } \\
\text { jual, biaya operasional, dan } \\
\text { lainnya }\end{array}$ \\
\hline
\end{tabular}

Sumber: Tim Pengabdian, 2021

\section{KESIMPULAN}

Pengabdian PKM Peningkatan Kualitas Produk Olahan Jamu Tradisional telah dapat dijalankan dengan baik dan tanpa halangan yang berarti. Adanya peningkatan pada segi produksi, pendapatan dan pengetahuan pada mitra menjadi kunci sukses keberhasilan program kegiatan ini. Dengan kerjasama tim pengabdian yang baik dan peran serta aktif dari penyuluh/narasumber dalam kegiatan pengabdian ini maka semuanya telah berjalan sesuai yang diharapkan dan harapannya dapat memberikan manfaat bagi mitra pengabdian masyarakat dalam keberlanjutan usaha dan Produksi Usaha jamu tradisional pada kelompok usaha Mitra. 


\section{UCAPAN TERIMA KASIH}

Tim Pengabdi mengucapkan terimakasih kepada Universitas Negeri Medan khususnya Lembaga Penelitian dan Pengabdian kepada Masyarakat Unimed dan Mitra Usaha Jamu Tradisional Jamu Harum dan Segar Sari yang telah mendukung terlaksananya kegiatan program Pengabdian kepada Masyarakat ini.

\section{DAFTAR PUSTAKA}

Le Prestre, P. G. (2017). Governing global biodiversity: The evolution and implementation of the convention on biological diversity. In Governing Global Biodiversity: The Evolution and Implementation of the Convention on Biological Diversity. Routledge. https://doi.org/10.4324/9781315253930

Mochamad Reza Rahman, Oktavianto, M. R., \& Paulinus. (2013). Perkembangan UMKM ( Usaha Mikro Kecil Dan Menengah ) Di Indonesia. Jurnal Ilmiah Cano Ekonomos, 6(1), 377-386.

Murniati, W. (2020). Drafting Assistance On Traditional Jamu UMKM. Empowerment Society, 3(2), 57-61. https://doi.org/10.30741/eps.v3i2.590

Saptaningtyas, A. I., \& Indrahti, S. (2000). Dari Industri Jamu Tradisional ke Industri Jamu Modern : Perkembangan Industri Jamu Sido Muncul dalam Mempertahankan Eksistensi Perusahaan Tahun 1951-2000. Historiografi, 1(2), 174.

Setyo, T. (2017). Analisis Terhadap Faktor-Faktor Kebangkrutan Pada Industri Jamu Tradisional Parang Husada di Kabupaten Kediri. In SimkiEconomic (Vol. 1, Issue 5, pp. 1-15). Simki-Economic.

Widowati, L., Sampurno, O. D., Siswoyo, H., Sasanti, R., Nurhayati, N., \& Delima, D. (2020). Kajian Kebijakan Pemanfaatan Obat Tradisional Di Fasilitas Pelayanan Kesehatan Pada Era Jaminan Kesehatan Nasional. Buletin Penelitian Sistem Kesehatan, 23(4), 246-255. https://doi.org/10.22435/hsr.v23i4.3379 